NOTA

\title{
OCCURRENCE OF A COUPLE OF Callorhinchus callorynchus (LINNAEUS 1758) OFF SOUTHERN BRAZIL
}

\author{
YAN GOWERT* \& MARIA CRISTINA ODDONE FRANCO
}

Universidade Federal do Rio Grande, Instituto de Ciências Biológicas, Setor de Morfologia/Pesquisa em Chondrichthyes, Av. Itália, Km 8 s/n, Campus Carreiros, 96203-900 Rio Grande, RS, Brasil.

${ }^{*}$ Corresponding author: yangowert @ furg.br

\begin{abstract}
In this paper the occurrence of two specimens of the elephant fish, Callorhinchus callorynchus is recorded. Despite being common off Uruguay and Argentina, the species is occasionally caught in South Brazil. As a consequence, information on the populations of this species is not available.
\end{abstract}

Key words: Chondrichthyes, Holocephalli, fishes, bottom trawl fisheries

\section{RESUMEN}

Ocurrencia de una pareja de Callorhinchus callorynchus (Linnaeus 1758) en aguas del sur del Brasil. En este artículo se registra la ocurrencia de dos especímenes del pez Gallo, Callorhinchus callorynchus. Pese a ser común aguas frente a Uruguay y Argentina, la especie no es comúnmente capturada en el sur del Brasil. Como consecuencia, no se dispone de información sobre las poblaciones de esta especie.

Palabras clave: Condríctios, holocéfalos, peces, pesca de arrastre de fondo

The Order Chimaeriformes comprises six extant genera with 49 species (Weigmann, 2016). Systematically, this group is composed of three families. The Family Callorhinchidae includes the chimaeras with snout elongate, flexible, hoe-shaped process (Nelson, 2016). The four living species of genus Callorhinchus are restricted to temperate waters of the Southern Hemisphere (Didier, 2004). The species is common in Uruguayan and Argentinean waters (Figueiredo, 1977; Di Giácomo \& Perier, 1991; Chierichetti, 2017). Off Brazil, elephant fishes are recorded occasionally. They have been reported for the litoral of São Paulo state, around the island of São Sebastião (230 45' 36" S; $45^{\circ}$ 24' 35" W). The elephant fish, Callorhinchus callorynchus (Linnaeus, 1758) is occasionally caught in small-scale fisheries off Santa Catarina State in Brazil (Mazzoleni \& Schwingel, 1999). The aim of this work is to record the occurrence of two specimens of $C$. callorynchus off South Brazil. The specimens were obtained from a commercial fishing trip along the coast of Rio Grande do Sul (South of Brazil), carried out from September $22^{\text {nd }}$ to $30^{\text {th }}$, 2011. The fishing area was located between latitudes $34^{\circ} 28^{\prime} \mathrm{S}$ and $31^{\circ} 29^{\prime} \mathrm{S}$ at depths between 15 and $142 \mathrm{~m}$. The precise depth of the fishing haul with occurrence of the chimaeras was not reported by the skipper. Taxonomic identification of the individuals was performed according to Figueiredo (1977). The specimens were taken to the laboratory (Laboratório de Morfologia II, Instituto de Ciências Biológicas, FURG), for fixation and analysis. From each specimen, total length ( $T L, \mathrm{~cm})$, total weight (TW, g), sex, total clasper length $(\mathrm{CL}, \mathrm{cm})$ measured from cloacal to extreme distal aspect of the same and the total length of the dorsal spine (DSL, cm) were recorded. To assess the maturity stage, the clasper calcification degree (male) and the aspect of the ovaries and oviductal gland in the female were observed. The uteri were also examined.

Based on the observation of the secondary sexual characters, one of the specimens was identified as male while the other was female (Fig. $1 \mathrm{~A}$ y B). Both of them were adult. Uteri were empty. The male had a TL of $70.0 \mathrm{~cm}$; the $\mathrm{CL}$ was $9.0 \mathrm{~cm}$, the DSL was $11.8 \mathrm{~cm}$ and the TW was $1317.5 \mathrm{~g}$. The female was $65.0 \mathrm{~cm} \mathrm{TL}$, and $1420.5 \mathrm{~g} \mathrm{TW}$. The female DSL could not be registered because the spine was incomplete. The first specimen reported from Brazilian waters was captured in 1928 at Praia Grande, in the vicinities of the city of Santos, Sao Paulo State (Miranda Ribeiro, 1928). Records of $C$. callorynchus in Brazilian waters have been based on single specimens, suggesting that it may be solitary or occur in small schools (Moreira et al., 1993; Di Dario, 2011). Although this record represents an important antecedent for the study of the biology and ecology of this family, it is not possible to conclude anything about the population of this family off south of Brazil. One major question is whether or not elephant fishes occurring off south Brazil are the same large population with those of Uruguay and Argentina (where it is common). 

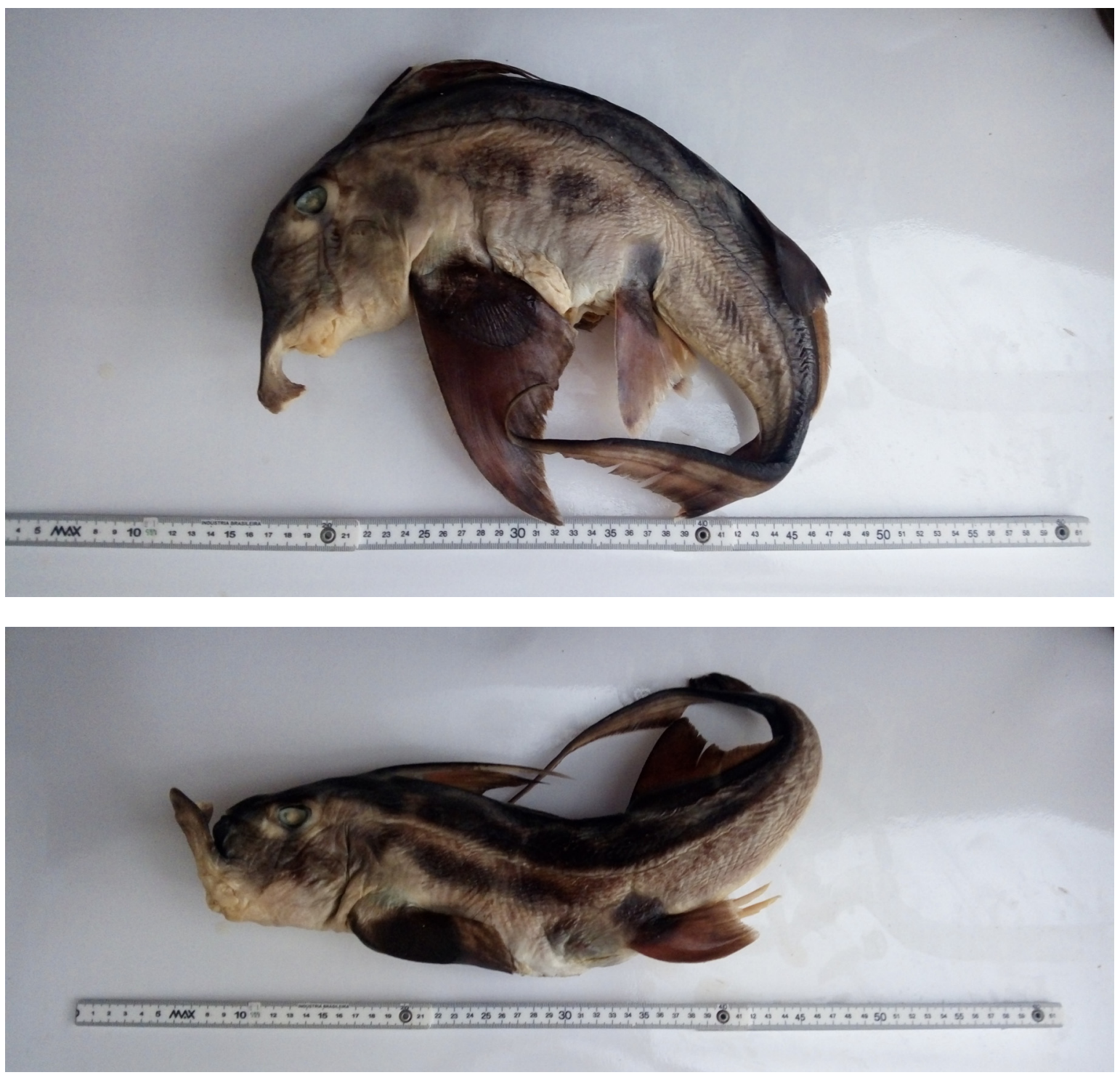

Fig 1. The two specimens of Callorhinchus callorynchus captured off South Brazil in 2011; female (A) and male (B). Black bar represents $10 \mathrm{~cm}$.

\section{ACKNOWLEDGMENTS}

We are grateful to skipper Charles Da Hora and crew of the fishing vessel "Menina Lybia" and to MSc. Alexander Basallo Melo for samples collection.

\section{REFERENCES}

Chierichetti M.A., Scenna L.B., Di Giácomo E.E., Ondarza P.M., Figueroa D.E. \& Miglioranza K.S.B. 2017. Reproductive biology of the cockfish, Callorhinchus callorynchus
(Chondrichthyes: Callorhinchidae), in coastal waters of the northern Argentinean Sea. Neotropical Ichthyology, 15: 2.

Didier D.A. 2004. Phylogeny and classification of extant Holocephali. In: Carrier J.C., Musick J.A. \& Heithaus M.R. (Eds.) Biology of sharks and their relatives, pp. 173-201. Boca Raton, Florida.

Di Dario F., Petry A.C., Mincarone M.M., Pereira M.M.S. \& dos Santos R.M. 2011. New records of coastal fishes in the northern Rio de Janeiro State, Brazil, with comments on the biogeography of the south-western Atlantic Ocean. Journal of Fish Biology, 79: 546-555. 
Di Giácomo E.E. \& Perier M.R. 1991. Evaluación de la biomasa y explotación comercial del pez gallo (Callorhynchus callorhynchus) en el Golfo San Matías, Argentina. Frente Marítimo, $9(A)$ : 7-13.

Figueiredo J.L. 1977. Manual de peixes marinhos do sudeste do Brasil: Introdução. Cações, raias e quimeras, Museu de Zoologia da Universidade de São Paulo, São Paulo. 111 pp.

Mazzoleni R.C. \& Schwingel P.R. 1999. Elasmobranch species landed in Itajaí harbor, southern Brazil. Notas Téc. FACIMAR, 3: 111-118.

Miranda Ribeiro A. 1928. Callorhynchus callorhynchus L. Boletim do Museu Nacional, Rio de Janeiro, 4: 47-48.

Moreira W. Jr., Gomes U.L. \& Marques A.R. 1993. Registro do "tubarão-de-sete-guleras"
Heptranchias perlo (Bonnaterre, 1788) e do "peixe elefante" Callorhynchus callorhynchus (Linnaeus, 1758) (Pisces, Chondrichthyes) no litoral do Estado do Rio de Janeiro, Brasil. Acta Biologica Leopoldensia, 15: 145-150.

Nelson J.S., Grande T.C. \& Wilson M.V.H. 2016. Fishes of the World. $5^{\text {th }}$ ed. Hoboken, New Jersey. 752 pp.

Weigmann S. 2016. Annotated checklist of the living sharks, batoids and chimaeras (Chondrichthyes) of the world, with a focus on biogeographical diversity. Journal of Fish Biology, 88: 837-1037.

Fecha de Recepción: 24 de febrero de 2019 Fecha de Aceptación: 06 de setiembre de 2019 